\title{
SEMIOLINGUISTICS OF SACRED POWER
}

\author{
Tatyana N. Astafurova \\ Volgograd State University, Volgograd, Russia \\ Andrey V. Olyanich \\ Volgograd State Agrarian University, Volgograd, Russia
}

\begin{abstract}
The paper addresses the phenomenon of sacred power as the oldest regulator of the behavior of ethnos from the perspective of social semiotics: it includes the definition of this type of power, its basic spheres of actualization (religious and magic) and identification of its lingual-semiotic, ethno-cultural and discourse parameters in the various semiolinguistic ways: sacred objects and buildings, actions and rituals, verbal texts, language formulas being included. The sacred is defined as something inexpressible by its nature, it is stated that it can be approximated to personal understanding only through the symbol. Sacred power generates semiolinguistic space in the form of verbal and non-verbal signs of various form and content that perform their protective impact on the objects of sacred power. Special attention is paid to genres and rituals through which sacred power is exercised. The authors highlight the phenomenon of ceremony that gives a sacred meaning to human actions, and show what special rituals are linked to communicating with the sacred power.

The semiotic aspect of religious and magical protection is differentiated by the quality of the sign: religious semiolinguistics involves sacred myths and symbols, and magic semiolinguistics is based on chasing-out and purifying magic with its signs and texts.

Key words: sacred power, semiolinguistics, sign, ritual, religion, magic, genre.

Citation. Astafurova T.N., Olyanich A.V. Semiolinguistics of Sacred Power. Vestnik Volgogradskogo gosudarstvennogo universiteta. Seriya 2, Yazykoznanie [Science Journal of Volgograd State University. Linguistics], 2018, vol. 17, no. 4, pp. 180-187. DOI: https://doi.org/10.15688/jvolsu2.2018.4.17

УДК 81 '22

ББК 81.002

Дата поступления статьи: 30.08.2018 Дата принятия статьи: 28.09.2018
\end{abstract}

\section{ЛИНГВОСЕМИОТИКА САКРАЛЬНОЙ ВЛАСТИ}

\author{
Татьяна Николаевна Астафурова
}

Волгоградский государственный университет, г. Волгоград, Россия

\section{Андрей Владимирович Олянич}

Волгоградский государственный аграрный университет, г. Волгоград, Россия

\footnotetext{
Аннотация. В статье с точки зрения социальной семиотики рассматривается феномен сакральной власти как старейшего регулятора поведения этноса: дается определение этого типа власти, описываются основные сферы ее актуализации (религиозная и магическая), идентифицируются языковой, семиотический, этнокультурный и дискурсивный параметры, выделяются разные лингвосемиотические приемы трансляции сакрального в материальных знаках (сакральных объектах и зданиях, действиях и ритуалах, текстах, языковых формулах, демонстрирующих сакральную власть). Сакральность определяется как нечто, не имеющее выражения. Подчеркивается, что осознание сакрального проходит через личностное восприятие его символики. Сакральная власть порождает лингвосемиотическое пространство в виде вербальных и невербальных знаков различной формы и содержания, которые оказывают протективное воздействие на ее объекты. Особое внимание уделяется жанрам и ритуалам, посредством которых репрезентируется этот тип власти.
} 
Выделяется ритуальность сакральных церемоний как феномен, придающий сакральную значимость действиям человека, показывается, как специальные ритуалы связаны с передачей и утверждением сакральной власти. Семиотический аспект религиозной и магической протекции дифференцируется в зависимости от качества знака: религиозная лингвосемиотика включает священные мифы и символы, магическая лингвосемиотика основана на отгонной и очистительной магии с ее знаками и текстами.

Ключевые слова: сакральная власть, лингвосемиотика, знак, ритуал, религия, магия, жанр.

Цитирование. Астафурова Т. Н., Олянич А. В. Лингвосемиотика сакральной власти // Вестник Волгоградского государственного университета. Серия 2, Языкознание. - 2018. - Т. 17, № 4. - С. 180-187. - DOI: https://doi.org/10.15688/jvolsu2.2018.4.17

\section{The phenomenon of sacred power}

The phenomenon of power, the increment of any new knowledge about the nature of power and the mechanisms of domination is one of the most ancient and at the same time the youngest spheres of scientific research. The phenomenon of power, varieties of which are traditionally recognized as sacral, absolute and institutional [Astafurova, Olyanich, 2017], is one of the most important types of social interaction, as a result of which the ruling entity realizes their will and interests.

Sacred power is defined as the oldest regulator of the behavior of population, which makes believers subject to the basic norms of social behavior (Christian Commandments) and seek protection from God / mystical forces in case of their non-observance. The goal of this article includes the consideration of the phenomenon of sacred power, the identification and description of its semiolinguistic, ethno-cultural and nominative characteristics.

Sacredness (from the Latin sacer dedicated to God and Sacrum - sacred) is possession of an object (artifact, phenomenon, animal, person) with sacred content of unusual quality. The concept sacred expresses the idea of the division of the world into profane (secular, ordinary) and sacral (sacred, esoteric). The ratio of these two worlds is characterized by certain features:

1. The sacred is inexpressible by its nature and can be approximated to the person / his understanding only through the symbol;

2. Communication with the sacred requires a special ritual, a ceremony that gives a sacred meaning to human actions.

Historical analysis allows us to establish the stages of the evolution of the concept of the sacred. The first stage under the sacral is understood all the unusual (both positive, holy, and negative, damned). The second stage the sacral denotes the existing order, the norm and the pattern of actions. The third stage - the sacral functions as sacred ideal acts, as a synthesis of categories of mind and morality [Parsons, 2002]. The sacred world is a collection of sacred and mystical things to which socially significant meanings is loaded thus reflecting the social nature of man [Gultaeva, 2000].

The sacred is the natural mechanism of the reproduction of culture and is rooted in the very nature of man, who gives his world sacred and mystical meanings and significances, opposing them to cognitive and social chaos [Berger, 1969]. Sacred power is associated with the spread of religious and esoteric outlook and attitude in personal and private relationships. The main sign of sacredness is the appearance in linguistic culture of religious symbols and plots as semantic, explanatory and authorizing schemes. Sacralization reflects the historical dynamics of formation and development of human society and culture - its social (politics, law, education) and personal (family, economic structure, life, holidays) life.

In the new millennium, there are clear signs of the growing interest to religion and magic, the emergence of a large number of non-traditional religious and mystical currents. Among the causes of modern sacralization, which are extremely different in their content and significance, the researchers distinguish:

- roots of religion (epistemological, psychological, social, daily routine, etc.) as a set of conditions for its appearance and reproduction; - political conjuncture as a factor of involving religion in the sphere of social management and power;

- interest in tradition as an integral element of the organization of human behavior; 
- crisis of the materialistic world view as a reason for searching of alternative protective schemes [Beznuk, 2003].

Alternative protective schemes, according to theosophists, include elements of folk (everyday) magic, in particular, sacralized signs of transitional (apotropic) and purifying (cathartic) magic [Gultaeva, 2000]. This world lives by its signs, and the destinies of people in it are revealed by fortune telling, corrected by conspiracies, spells and prayers. It is inhabited by amazing creatures - sorcerers, witches, brownies; this world lives by its ancient laws and the mystical experience of our ancestors comes to life in it. But it was just that small, every day, improvised sorcery, the provincial skill from time to time to use not even the forces, but things that the townspeople could hardly believe, but which nonetheless existed [Bushkov, 2007]. So, an element of the mystical is introduced into the understanding of the sacred and its semiolinguistic phenomena, their properties and relationships are explored [Gultaeva, 2000; Konovalova, 2007].

Sacred power is actualized in religious, mystical and magical spheres, relating to religious worship and magical ritual (Dictionary of Foreign Words). Dictionary definitions allow us to clarify the essence of this phenomenon: Sacral - 1. Religious and mystical values - faith, sacraments; 2. The totality of texts, language formulas, artifacts, buildings, etc., which is part of the system of religious and mystical practice (Atheistic Dictionary, p. 391). Cf. also: Sacral-Sacred (from the Latin sacrum sacredness) - the subject of religious faith; special beings, connections and relationships, which in various religions acquire supernatural and mystical character (Large Encyclopedic Dictionary).

Thus, the sacred power is a complex phenomenon, the significance of which is actualized by various semiolinguistic ways: verbal (texts ${ }^{1}$, language formulas), actional (acts, actions, rituals), object (things, buildings), personal (beings, characters, persons), etc. The main sphere of the semiosis of the sacred is faith and magic, which manifest themselves in religious and magical discourses - their semiotics, semantics, texts, rituals and rituals, respectively.

\section{Religious Semiolinguistics}

Cognition and cognitive development of man in the world around him and giving him life, inextricably linked to semiosis, understood as signification, that is, the process of semiotic representation of information and the use of signs in all spheres of natural and social life, where information processes take place [Mechkovskaya, 1998, p. 14]. The most ancient example of such a process is the formation of a system of signs that reflects the struggle of man with the forces of nature, which ensures the survival of man as a species. In this struggle, man relied on a universal religious-mystical system of signs, forming a special type of communication a protective one [Astafurova, Olyanich, 2007].

Decoding these signs, the society builds its communicative and pragmatic behavior in accordance with the received semiotic information; the need for protection forms an algorithm for counteracting the hostile forces of nature and becomes part of the irrational picture of the world of the ethnos in which the signs of mythological / theological and mystical representation exist. Their distinction is associated with different types of protection, due to:

- observance of religious commandments, moral norms of Christian morality in order to avoid punishment "in life after death";

- domestic (folk) magic as a means of protection from evil forces in the earthly life.

The semiotic aspect of religious and magical protection is differentiated by the quality of the sign: religious semiolinguistics involves sacred myths and symbols, magic semiolinguistics - sacral signs of apotropeic and cathartic magic [Konovalova, 2007].

The semiotics of religious protection correlates with the mythological symbol as a generalized notion of some indefinite divine power, evil or (rarely) beneficent, often determining the life destiny of a person. It is an instantaneously appearing and escaping terrible fateful force, which can not be called by name, with which one can not enter into any communication. Suddenly rushing, it immediately produces an action, and immediately disappears without a trace [Losev, 1982, p. 366]. The man's fear of this ambivalent power included cognitive defense mechanisms against it, which, on the one hand, were verbalized in mythological euphemisms [Chernikova, 2007], 
indirectly nominating God and his antagonist Satan; on the other hand, they demanded to follow the Commandments of God, appealing to the good deeds of a Christian.

Christian theonyms God and Lord date back to the Dutch Goode, German Gott, and to ancient Teutonic form Gudo, designating him to whom the appeal: "The word God is derived from the old Teutonic form gudo which means that is invoked (or worshiped) by sacrifice)" (Oxford English Universal Dictionary). Demonym Satan has developed from a Jewish sātān - adversary in court, in a dispute or war preventing the contrary, the prosecutor, eavesdropper, instigator, and the common name, which is perceived as a nickname of a nameless enemy.

The third Old Testament Commandment (taboo in the name of God) in the New Testament is not mentioned at all. And the ban on pronouncing the name of God and the demonym are preserved only in the oral tradition. The only difference is that the official church recognizes the taboo on the theonym, and the taboo on the demon becomes superstition.

The belief in the magical power of the name was not only in the Indo-European religions listed above, we also can find similar faiths among the Scythians and Sarmatians. In GermanicScandinavian mythology it was expressed in the creation of kennings (allegories) and euphemisms replacing the true names of the gods [Meletinsky, 1976] as a nominative mechanism for neutralizing fear. So, in English there are numerous euphemistic substitutions that form a ramified lexical system of theonyms, based on their phonetic deformation: Christ - Cripes, Cristopher Columbus, Chris, cricket; Lord Laws, Lawsy, Lor', Lawd, Lordy.

In addition, one of the most frequent ways of religious protection is the use of euphemisms based on the metaphorical transfer of God's power (the Almighty, the most High, Possessor of Heaven and Earth), the Guardian of human virtue (the shield of thy help, the everlasting arms, the sword of thy excellency, the shepherd) and the first principle of all that exists (the stone of Israel), the strict judge, severely punishing the unseemly acts and evil thoughts of man (Judge of all the earth, a mighty, and a terrible, which regardeth not persons, nor taketh reward, the fear of Isaac, a consuming fire).
In the English-speaking lingua-culture euphemistic transformation of the names of God's antagonists are also presented as the hierarchy of demons, established in universal religious practice. God's antagonists are nominated by:

- anthroponyms, accentuating the antiquity of the devil as a champion of evil (Old Bendy, Old Cain, Old Clough, Old Harry, Old Henry, Old Man, Old Ned, Old Nicky, Old Sam Hill);

- obsolete interjections of negative nature (the Old Dickens, the Old Divel);

- metaphorical and metonymic expressions (the Old deuce, Old Poker, Old Serpent, the tempter, evil, a beast with seven heads and ten horns, the false prophet) which are associated with figurative nominations of God's antagonists, tempting a person to commit adultery, fornication, lechery, lust, seditions, idolatry creation, witchcraft, hatred, variance, prudence, wrath, quarrel, heresies, envy, murders, drunkenness, revelling, gluttony, etc. [Astafurova, Olyanich, 2009].

In religious power Anglican protestants sought protection from demons, each of whom tempted Christians by one of the seven deadly sins: Asmodeus - lust, Beelzebub - gluttony, Mammon - greed, Belphegor - sloth, Satan wrath, Leviathan - envy, Lucifer - pride.

Sacred power is based on a prototype belief that the future or outcome of certain important events depends on the virtuous conduct of a Christian. Unlike a heathen, who trembled with fear of the gods as a slave before their cruel and willful master, Christians gave their destiny to the merciful God, who granted forgiveness and love under the observance of His basic Commandments. Any troubles were perceived as a penalty of God (a sign of divine disfavor) for deviating from the fulfillment of the prescribed rules and norms, regardless of the believer's involvement in these misfortunes. The form of protection from God's wrath was the salvation of sins through the texts of prayer, confession and communion as the main genres of a religious discourse [Astafurova, Olyanich, 2012].

The genres of a religious discourse are determined by the communication of man with God, the esoteric illocutionary potential, the set of intentions, the leading role in which is the search for protection from God and the redemption of punishment for unrighteous earthly life. In religious 
discourse, based on the characteristics of its generation and functioning, primary and secondary speech genres are distinguished. The primary ones include psalms, parables and prayers as precedent religious texts, primary sources; the secondary genres include preaching and confession as an interpretation of primary genres [Bobyreva, 2007]. A religious genre is a formal expression of ethnocultural beliefs. The definition of genres, therefore, corresponds to the study of that folk soil from which religious ideas have grown [Vereshchagin, Kostomarov, 1980, p. 68] and is the field of realization of a certain spectrum of social values and lingua-cultural concepts based on them [Slyshkin, 2004].

The protective function of the sacred text of the psalm (prayer) is realized through the nominations of the promise of salvation, defense, protection (For the sake of it, that thou hast not thy footsteps against a stone), and deliverance from the fear of the physical (Thou shalt go upon the lion and adder: the young lion and the dragon shalt thou tread under thy feet) and moral (There shall be no evil happen unto thee; I will deliver him) suffering in case a Christian loves God and fulfills his commandments (Because he hath set his love upon me, I will deliver him: I will set him up, because he hath known my Name).

Parables $^{2}$ are the basic element of pastoral conversations, which describe examples of the protection of true Christians by God and the miracles performed by Him (the Lazarus' resurrection by Christ, the healing of a leper, lame, blind, etc.). Most of the parables are built on the use of allegory, in which its true meaning is hidden, but easily predictable, understood and derived from the content. Compositionally the parable consists of:

1) Biblical scripture as the primary source;

2) a meditative part, which is a moral instruction-commentary of a priest, who explains the ethical essence of the situation described;

3) the appeal part (short prayer), confirming the willingness of a Christian to keep the covenants of the Lord.

Confessions are constructed according to the principle of the text that reveals the truth of the soul ... and includes different types of biographies, narratives that reveal the negative aspects of life [Arutyunova, 1999, p. 622]. Confessions like penance before God of one's guilt in the deed guarantee the forgiveness of sins (absolution), the forgiveness of the sinner by God in the event of his sincere repentance. Compositionally, confession does not have a definite structure and is a "stream of consciousness".

In response to confession, God refers to man through the word of man, which fulfills an official role in relation to the original source: the preacher's speech does not simply convey to the hearer the word and teaching of God, but also in a certain way interprets it. The sermon is a priest's instruction, an explanation of the principles of faith and virtuous life. The sermon is distinguished by a rigid binding to the source text, which is interpreted during the sermon. The composition structure includes the initiation, the main and the final parts. The beginning contains illustrations of the basic idea of the sermon at the everyday level. The main part confirms the firmness and authenticity of Christian dogmas, condemns their violation through allusions, quotations, precedent names and events from the Holy Scripture. The final part is a call and parting for the fulfillment of the Christian commandments as protection from punishment for sins.

The basic concepts of faith are directly related to the human value-cognitive guidelines: each ethnos integrates its beliefs in the form of a national religious concept-sphere, the cognitive development of which forms a national identity, oriented toward theosophical dogmas of Orthodoxy, Catholicism, Protestantism, Anglicanism, etc. Religious sacred power stands as a special irrationality of a universal nature, in contrast to a mystical sacral power - an ethnically unique one, through which the transfer of socio-protective experience from generation to generation is carried out.

\section{Magic semiolinguistics}

Sacred power correlates with the axiological system of magic semiolinguistics, which is based on the intentional dyad 'virtue - crime.' It includes positive value constants (philanthropy, diligence, honesty, chastity, generosity, health, etc.) contrasted with negative ones - antivalues (hatred, deception, slander, disease, corruption, evil eye, greed, adultery, etc). The axiological significance of these constants is reflected in the ethno specific system of magical signs, symbols, and rituals [Astafurova, Olyanich, 2012]. 
Household magic as a kind of sacred power has a strong suggestive potential and realizes the basic strategies of warning, correction and protection. Warning is aimed at prevention from possible dangers reflected in ethnically specific signs. Correction (purifying magic) is associated with the healing of ailments and the normalization of the deviant psychosomatic state through algorithmic, semioticially rich rituals and conspiracies. Protection (chasing-out magic) - is protection from hostile external influences through spells and symbolically rich rituals.

Magic semiolinguistics involves into sacralized communication signs of apotropeic (chasing-out) and cathartic (purifying magic) [Gultaeva, 2000] aimed at the removal of domestic fears of disease, failures, negative influence of others on the fate of a person. It is represented by:

- magical artifacts (amulets, talismans, tools, etc.);

- magical texts (conspiracies, spells, signs describing the mechanism of human influence on the outside world in protection against its negative influence);

- magical rituals (formalized sequence of actions accompanying magical texts).

Magic signs protect against disease and damage (amulet $\mathrm{n}=$ an object worn as protection against illness or injury); failure and evil eye (charm $\mathrm{n}=$ an item worn as in warding off evil) and provide the protection of the good forces (talisman $\mathrm{n}=$ an object with magical powers of protection).

The tools of magic semiolinguistics include mystical artifacts (wax figure, dummies, candle, magic brew, needle, thread, ring, mirror), which are attributed to the suggestive force within the protective ritual. A special suggestive power is given to magic herbs, which:

- guard against evil spirits, witchcraft: basil used to protect against all forms of evil and attracts good luck and wealth; dill - used to protect against demons and evil ghosts;

- protect from elements and human vices: thistle - used in protection against thieves; oak used for healing and protection against lightning, bad luck, and evil beings;

- remove spoilage, the evil eye: juniper used to guard against black magic, enemies, disease and accidents; lavender - used for protection against evil eye;
- cleanse of diseases, depression and nightmares: rosemary - used to prevent nightmares, preserve youthfulness; mistletoe - a great protection herb to heal wounds quickly;

- free from the ill effects of ill-wishers: elder - used to break the power of curses, to attract good luck, love, and prosperity;

- bring prosperity, luck, love, physical health, fulfillment of desires: acacia - used to attract money, inspire love; daisy - used to attract good luck, and return lost loves; hazel - to increase fertility, protect against fire and all evils; fern used to attract good luck and to bring rain; mint used for money attracting, increasing sexual desire [Chernyavskaya, 2008].

Magic texts, pronounced according to special rules and in special conditions, are symbolically saturated and have a stable formal-content structure that reflects the features of mystical (irrational) consciousness. A different combination of prognostics, suggestion and active semiotics is actualized in magical texts as linguistic and cultural signs which provide:

- warning of danger, anticipation of event in the form of advice (omen = prognostic sign for a person to be aware of his good / bad luck - prognostic signs);

- performance of apotropeic (chasing-out) and cathartic (purifying) magic (chant $=a$ suggestive monotonous rhythmic and rhymed protection verse or conspiracy);

- performance of magic rituals that support magical texts (spell with its Latin etymological doublet charm $=$ an action and a magic word, verse or formula thought to have magical power).

The formal content structure and subject matter of the sacred magic text are relatively stable, but they correlate differently with each other:

- in omens the subject matter of predictions is variable, but the cause-effect syntactic structure 'if ... then' is rigid;

- conspiracies persistently use clichéd language formulas, but their subject is limited primarily to psychosomatic states of subjects of magical impact;

- spells are characterized by variability of subject matter, but their actional structure is rigidly fixed;

- rituals are distinguished by a rigid symbolic / semiotic system. 
Thus, the semiolinguistics of sacred power, actualized in the system of signs, texts and discourse forms a lingua-cognitive space of protective communication with the help of religious and magical signs, nominations, texts accompanying religious and magical rituals.

\section{NOTES}

${ }^{1}$ A sacred text is a suggestive text, symbolically saturated, possessing a relatively stable formalcontent structure, which, according to special rules or in special circumstances, reflects features of mythological consciousness [Konovalova, 2007].

${ }^{2}$ Parables $=$ short simple stories which teach moral righteous lessons, especially from the Bible (Longman Dictionary of English Language and Culture).

\section{REFERENCES}

Arutyunova N.D., 1999. Language and the World of Man. Moscow, Yazyki russkoy kultury Publ. $896 \mathrm{p}$.

Astafurova T.N., Olyanich A.V., 2007. Lingua-Pragmatics of Protective Communication. Professional Communication: Problems of the Humanities. Volgograd, Niva Publ., iss. 2, pp. 9-15.

Astafurova T.N., Olyanich A.V., 2009. Lingua-Semiotics of Sacredness: Sign, Word, Text. Vestnik Volgogradskogo gosudarstvennogo universiteta. Seriya 2, Yazykoznanie [Science Journal of Volgograd State University. Linguistics], no. 1, pp. 80-87.

Astafurova T.N., Olyanich A.V., 2012. Linguo-Semiotics of Social Phobia Neutralization. Vestnik Volgogradskogo gosudarstvennogo universiteta. Seriya 2, Yazykoznanie [Science Journal of Volgograd State University. Linguistics], no. 1, pp. 86-92.

Astafurova T.N., Olyanich A.V., 2017. Lingual Semiotics of Absolute Power in the Tudors' Times. Vestnik Volgogradskogo gosudarstvennogo universiteta. Seriya 2, Yazykoznanie [Science Journal of Volgograd State University. Linguistics], vol. 16, no. 4, pp. 167-176. DOI: https://doi.org/10.15688/ jvolsu2.2017.4.15

Berger P.L., 1969. The Social Reality of Religion. London, Pergamon Press. 390 p.

Beznuk D.K., 2003. The Fundamentals of the Sociology of Religion. Minsk, Bel. Science Publ. $230 \mathrm{p}$.
Bobyreva E.V., 2007. Religious Discourse: Values, Genres, Strategies. Dr. philol. sci. diss. Volgograd. $465 \mathrm{p}$.

Bushkov A., 2007. The Witch. Adventurous-Mystical Fairy Tale for Adults. Moscow, Olma Media Group Publ. 340 p.

Chernikova E.M., 2007. The Euphemization of the Onyms and Demons in Some Indo-European and Afrasian Languages. Cand. philol. sci. diss. Chelyabinsk. 254 p.

Chernyavskaya T.V., 2008. Discursive Space of English Prejudices. Cand. philol. sci. abs. diss. Volgograd. $18 \mathrm{p}$.

Gultaeva N.V., 2000. The Language of the Russian Conspiracy: The Lexicon. Cand. philol. sci. abs. diss. Ekaterinburg. 20 p.

Konovalova N.I., 2007. Sacred Text as a Linguistic and Cultural Phenomenon. Dr. philol. sci. abs. diss. Moscow. $50 \mathrm{p}$.

Losev A.F., 1982. Sign. Symbol, Myth. Works on Linguistics. Moscow, Izd-vo Moskovskogo universiteta. $479 \mathrm{p}$.

Mechkovskaya N.B., 1998. Language and Religion. Moscow, Grand Publ. 352 p.

Meletinsky E.M., 1976. Poetics of Myth. Moscow, Nauka Publ. $407 \mathrm{p}$.

Parsons T., 2002. Societies: Evolutionary and Comparative Perspectives. Moscow, Akademicheskiy proekt Publ. $538 \mathrm{p}$.

Slyshkin G.G., 2004. Lingua-Cultural Concepts and Meta-Concepts. Dr. philol. sci. abs. diss. Volgograd. $39 \mathrm{p}$.

Vereshchagin E.M., Kostomarov V.G., 1980. LinguaCultural Theory of the Word. Moscow, Russian language Publ. $320 \mathrm{p}$.

\section{DICTIONARIES}

Atheistic Dictionary - Abdusamedov A.I., Aleynik R.M., Alieva B.A. (eds.), 1984. Atheistic Dictionary. Moscow, Politizdat Publ. 512 p.

Dictionary of Foreign Words - Komlev N.G., 1999. Dictionary of Foreign Words. Moscow, EKSMO-Press, $1999.669 \mathrm{p}$.

Large Encyclopedic Dictionary - Prokhorov A.M. (ed.), 2001. Large Encyclopedic Dictionary. Moscow, Bolshaya Rossiyskaya entsiklopediya Publ. 1479 p.

Longman Dictionary of English Language and Culture - Longman Dictionary of English Language and Culture. Longman, 1998. 1568 p.

Oxford English Universal Dictionary - Oxford English Universal Dictionary. URL: http://www.oed.com 


\section{Information about the Authors}

Tatyana N. Astafurova, Doctor of Sciences (Philology), Professor of Department of German and Romanic Philology, Volgograd State University, Prosp. Universitetsky, 100, 400062 Volgograd, Russia, pic@volsu.ru, http://orcid.org/0000-0002-1299-8109

Andrey V. Olyanich, Doctor of Sciences (Philology), Professor of Department of Foreign Languages, Volgograd State Agrarian University, Prosp. Universitetsky, 26, 400002 Volgograd, Russia, aolyanich@mail.ru, http://orcid.org/0000-0003-3990-5707

\section{Информация об авторах}

Татьяна Николаевна Астафурова, доктор филологических наук, профессор кафедры германской и романской филологии, Волгоградский государственный университет, просп. Университетский, 100, 400062 г. Волгоград, Россия, pic@volsu.ru, http://orcid.org/0000-0002-1299-8109

Андрей Владимирович Олянич, доктор филологических наук, профессор кафедры иностранных языков, Волгоградский государственный аграрный университет, просп. Университетский, 26, 400002 г. Волгоград, Россия, aolyanich@mail.ru, http://orcid.org/0000-0003-3990-5707 